\title{
PENGARUH HIDROTERAPI KAKI TERHADAP PENURUNAN SKOR INSOMNIA PADA LANJUT USIA DI PANTI WERDHA MUHAMMADIYAH KOTA PROBOLINGGO
}

\section{(EFFECT OF FEET'S HYDROTHERAPY TO REDUCTION OF INSOMNIA SCORES AT ELDERLY IN PANTI WERDHA MUHAMMADIYAH PROBOLINGGO CITY)}

\author{
Setyoadi $^{1 *}$, Yansa Agustiawan Eka Putra ${ }^{2}$ \\ ${ }^{1}$ Program Studi Ilmu Keperawatan Fakultas Kedokteran Universitas Brawijaya \\ ${ }^{2}$ Mahasiswa Program Studi Ilmu Keperawatan Fakultas Kedokteran Universitas Brawijaya \\ Jl. Veteran No. 1 Malang 65145 \\ *e-mail: setyoadi@ub.ac.id
}

\begin{abstract}
ABSTRAK
Insomnia merupakan gangguan tidur yang paling sering ditemukan pada lanjut usia. Lanjut usia mengalami insomnia karena faktor fisiologis yang semakin menua sehingga sekresi hormon melatonin berkurang. Hidroterapi kaki merupakan salah satu cara non-farmakologi dengan cara merendam kaki dalam air hangat dengan suhu 30-39 derajat Celsius yang akan memberikan efek sopartifik atau efek ingin tidur. Tujuan dari penelitian ini untuk mengidentifikasi pengaruh hidroterapi kaki terhadap penurunan skor insomnia pada lanjut usia di Panti Werdha Muhammadiyah Kota Probolinggo. Desain penelitian dalam penelitian ini adalah Pra-eksperimental dengan pendekatan One Grup Pre Test - Post Test Design. Pemilihan sampel dilakukan menggunakan teknik simple random sampling. Sampel penelitian yaitu lanjut usia yang berusia 60-90 tahun dan mengalami insomnia sebanyak 16 responden. Analisa data statistik yang digunakan adalah paired t-test. Pengumpulan data dengan menggunakan kuesioner Insomnia Rating Scale yang dimodifikasi oleh Kelompok Studi Psikiatri Biologi Jakarta (KSPBJ) sesuai dengan kondisi Lansia di Indonesia. Hasil penelitian, didapatkan Mean hasil pengukuran Pre Test skor insomnia sebesar 27,43 dan Mean hasil pengukuran Post Test skor insomnia sebesar 23,93. Hasil uji statistik menggunakan paired $t$-test dengan $\alpha=0,05$ didapatkan nilai signifikansi 0,000 atau signifikansi $<0,005$. Kesimpulan dari penelitian ini yaitu ada pengaruh dari hidroterapi kaki terhadap penurunan skor insomnia pada lanjut usia. Disarankan hidroterapi kaki dapat digunakan sebagai salah satu cara untuk menurunkan skor insomnia pada lanjut usia yang mengalami insomnia.

Kata kunci: Hidroterapi Kaki, Lanjut Usia, Insomnia.
\end{abstract}

\section{ABSTRACT}

Insomnia is a sleep disorder that is most commonly found in the elderly. Elderly people suffered insomnia because the aging physiological factors that reduced secretion of the hormone melatonin. Feet's hydrotherapy is one of the non-pharmacological ways by soaking feet in warm water with a temperature of 30-39 degrees Celsius who will give the sopartifik effect or want to sleep effects. The purpose of this study are to identify the Effect of Feet's Hydrotherapy to Reduction of Insomnia Scores at Elderly in Panti Werdha Muhammadiyah Probolinggo City. Design of this research is the Pre-Experimental with an approach One Group Pre Test - Post Test Design. Sample selection was done using simple random sampling technique. The research sample that is aged 60-90 years old and suffered insomnia as many as 16 respondents. Analysis of statistical data used is the paired t-test. Collecting data using questionnaires Insomnia Rating Scale modified by Jakarta Biological Psychiatry 
Study Group (KSPBJ) according to the Elderly's conditions in Indonesia. Results of research, measurement results obtained Mean of pretest score of insomnia are 27,43 and measurement results Mean of Post Test score of insomnia are 23,93. Statistical test results using a Paired T-Test with $\alpha=0,05$ are obtained significance values 0,000 or significance $<0.005$. The conclusion from this research that there is an influence of feet's hydrotherapy to decrease insomnia scores in elderly. Suggested feet's hydrotherapy can be used as one way to decrease insomnia scores in elderly who experience insomnia.

Keywords: Hydrotherapy, Elderly, Insomnia

\section{PENDAHULUAN}

Jumlah lansia yang terus meningkat di Indonesia ini menarik untuk di amati perkembangannya. Kantor Kementerian Koordinator Kesejahteraan Rakyat (KESRA) melaporkan, jika tahun 1980 usia harapan hidup (UHH) 52,2 tahun dan jumlah lansia 7.998 .543 orang $(5,45 \%)$ maka pada tahun 2006 menjadi 19 juta orang $(8,90 \%)$ dan UHH juga meningkat (66,2 tahun). Pada tahun 2010 perkiraan penduduk lansia di Indonesia akan mencapai 23,9 juta atau 9,77 \% dan UHH sekitar 67,4 tahun. Sepuluh tahun kemudian atau pada 2020 perkiraan penduduk lansia di Indonesia mencapai 28,8 juta atau $11,34 \%$ dengan $\mathrm{UHH}$ sekitar 71,1 tahun (Amir, 2007).

Hasil Sensus Penduduk tahun 2010 menunjukkan bahwa Indonesia termasuk lima besar negara dengan jumlah penduduk lanjut usia terbanyak di dunia. Jumlah lansia yang ada di Indonesia yakni mencapai 18,1 juta jiwa pada 2010 atau 9,6 persen dari jumlah penduduk. Persebaran penduduk lansia menurut provinsi, persentase penduduk lansia di atas $10 \%$ sekaligus paling tinggi ada di Provinsi DI Yogyakarta $(13,04 \%)$, Jawa Timur (10,40\%) dan Jawa Tengah $(10,34 \%)$. Secara global populasi lansia diprediksi akan mengalami peningkatan pada tahun 2020 (Amirta, 2007).

Peningkatan lansia ini juga tidak lepas dari masalah yang diderita. Lansia memerlukan perhatian khusus karena adanya siklus kehidupan manusia yang terus menerus mengalami proses penuaan secara biologis (Setyoadi \& Kushariyadi, 2011). Kane dan Ouslander (2009), ada beberapa masalah yang terjadi pada lansia yang salah satunya adalah gangguan tidur atau lebih dikenal dengan Insomnia.

Insomnia merupakan gangguan tidur yang paling sering ditemukan. Setiap tahun diperkirakan sekitar $20-50 \%$ orang dewasa melaporkan adanya gangguan tidur dan sekitar $17 \%$ mengalami gangguan tidur yang serius. Prevalensi gangguan tidur pada lansia cukup tinggi sekitar 67\%. Lansia dengan penyakit degeneratif sering melaporkan bahwa kualitas tidurnya kurang baik (Erliana, 2008).

Banyak usaha yang telah dilakukan untuk mencegah insomnia ini. Beberapa orang memilih pergi berkonsultasi ke dokter untuk menurunkan insomnianya. Lanjut Usia juga yang langsung meminum obat tidur tanpa berkonsultasi ke dokter dan tanpa memikirkan efek sampingnya. Hal lain yang sering dilakukan selain hal diatas adalah menghindari tidur siang agar pada malam hari lebih mudah tidur, tidak mengkonsumsi kafein dan nikotin, serta menghindari alkohol dan mematikan lampu saat tidur. Tindakan tersebut dirasa masih kurang efektif untuk mencegah terjadinya insomnia (Asmadi, 2008).

Berkenaan dengan hal diatas, penyembuhan terhadap insomnia sangat diperlukan untuk meningkatkan kualitas hidup lansia. Terapi yang ditawarkan untuk mencegah terjadinya insomnia antara lain terapi farmakologi dan nonfarmakologi. Teknik terapi yang mudah dan aman untuk dilakukan pada lansia adalah terapi nonfarmakologi. Terapi nonfarmakologi yang dapat dilakukan salah satunya adalah terapi rendam air hangat pada kaki atau sering disebut hidroterapi kaki (Setyoadi \& Kushariyadi, 2011). 
Hidroterapi kaki adalah bentuk dari terapi latihan yang menggunakan modalitas air hangat (Christina, 2012). Hidroterapi memiliki efek hidrostatik dan hidrodinamik. Terapi rendam air hangat pada kaki berguna untuk melebarkan pembuluh darah dan membuat peredaran darah menjadi lancer (Erliana, 2008). Hidroterapi kaki dapat memperbaiki mikrosirkulasi pembuluh darah dan vasodilatasi sehingga dapat meningkatkan kualitas tidur pada lansia (Setyoadi \& Kushariyadi, 2011).

Merendam kaki dalam air hangat yang bertemperatur $37-39^{\circ} \mathrm{C}$ akan menimbulkan efek sopartifik (efek ingin tidur) dan dapat mengatasi gangguan tidur (Guyton and Hall, 2006). Hasil penelitian yang pernah dilakukan di Panti Wredha di Kediri, kuantitas tidur lansia meningkat setelah dilakukan terapi rendam air hangat pada kaki yaitu yang awalnya kuantitas tidur lansia 4,88 jam perhari menjadi 6,20 jam perhari setelah dilakukan terapi rendam air hangat pada kaki (Kristyarini \& Kristanti, 2012). Penelitian di desa Mojojejer, Jombang juga menunjukkan hasil yang signifikan terhadap peningkatan kuantitas tidur pada lansia setelah dilakukan terapi rendam air hangat pada kaki sebelum tidur (Khotimah, 2012).

Hasil studi pendahuluan yang telah peneliti lakukan di Panti Werdha Muhammadiyah kota Probolinggo, di Panti Werdha tersebut lansia hidup mandiri dan bisa melakukan semua aktivitas harian secara normal. Lansia yang tinggal di Panti Werdha Muhammadiyah ada 20 orang, dan setiap lansia menempati sebuah kamar. Semua lansia di panti werdha tersebut diurus oleh sepasang suami istri. Peneliti melakukan screening insomnia terhadap lansia yang berada disana, dan hasilnya lansia di Panti Werdha tersebut mengalami masalah tidur atau biasa disebut insomnia. Screening yang dilakukan peneliti mendapatkan hasil sebesar $80 \%$ Lansia dari 13 orang Lansia yang dilakukan screening mengeluh mengalami gangguan tidur atau insomnia.
Lansia di Panti Werdha tersebut rata-rata sering terbangun di tengah malam dan susah untuk kembali melanjutkan tidur. Lansia juga banyak yang mengeluh tidak nyaman dengan kondisi seperti yang dialami sekarang ini.

Data banyaknya lansia yang mengalami insomnia dan masih sedikit intervensi yang diberikan kepada lansia yang mengalami insomnia, penulis tertarik untuk melakukan penelitian tentang "Pengaruh Hidroterapi Kaki Terhadap Penurunan Skor Insomnia pada Lanjut Usia" karena pada umumnya lansia yang mengalami insomnia belum diberikan intervensi yang tepat.

\section{METODE}

Desain penelitian dalam penelitian ini adalah Pra-Eksperimental dengan pendekatan One Grup Pre Test - Post Test Design. Sampel dalam penelitian ini adalah lansia berusia 60-90 tahun yang berada di Panti Werdha Muhammadiyah Kota Probolinggo yang mengalami insomnia. Sampel diambil dengan cara menghitung menggunakan rumus besar sampel Federer. Besar sampel yang didapatkan sebesar 16 responden. Instrument yang digunakan dalam penelitian ini yaitu kuesioner Insomnia Rating Scale dengan nilai uji validitas 0,89 dan nilai uji reabilitas 0,83 . Uji variabel menggunakan Uji Paired T-Test.

\section{HASIL}

Berdasarkan data hasil penelitian tentang karakteristik responden diketahui bahwa lanjut usia yang mengalami insomnia $50 \%$ berjenis kelamin laki-laki yaitu sebanyak 8 orang, dan $50 \%$ berjenis kelamin perempuan yaitu sebanyak 8 orang. Berdasarkan usia didapatkan bahwa responden yang berusia 60-70 tahun sebanyak 4 orang (25\%), responden berusia 71-80 tahun sebanyak 9 orang (56\%), dan responden berusia 81-90 tahun sebanyak 3 orang (19\%). Rata-rata usia responden yaitu 75 tahun. 
Tabel 1. Karakteristik Responden

\begin{tabular}{|l|l|l|l|}
\hline No & \multicolumn{1}{|c|}{$\begin{array}{c}\text { Karakte- } \\
\text { ristik }\end{array}$} & Jumlah & $\begin{array}{c}\text { Prosen } \\
\text { tase }\end{array}$ \\
\hline 1 & Jenis & & \\
& Kelamin & & \\
& Laki-Laki & 8 orang & $50 \%$ \\
& Perempuan & 8 orang & $50 \%$ \\
& Total & 16 orang & $100 \%$ \\
\hline 2 & Usia & & \\
& $60-70$ tahun & 4 orang & $25 \%$ \\
& $71-80$ tahun & 9 orang & $56 \%$ \\
& $81-90$ tahun & 3 orang & $19 \%$ \\
& Total & 16 orang & $100 \%$ \\
\hline
\end{tabular}

Tabel 2 menunjukkan dari hasil uji Paired T-Test didapatkan nilai signifikansi 0,000 dan untuk nilai $\alpha$ adalah 0,05 , yang berarti terdapat pengaruh dari hidroterapi kaki terhadap penurunan skor insomnia pada lanjut usia.

Tabel 2. Hasil Analisa Pengaruh Hidroterapi Terhadap Insomnia Lansia

\begin{tabular}{|l|l|l|c|c|}
\hline & Mean & $\begin{array}{c}\text { Std. } \\
\text { Deviasi }\end{array}$ & \multicolumn{1}{c|}{$t$} & Sig. \\
\hline Pre & 27,43 & 3,50 & 15,65 & 0,00 \\
\hline Post & 23,93 & 3,02 & \multicolumn{2}{|l}{} \\
\hline
\end{tabular}

\section{PEMBAHASAN}

\section{Skor Insomnia Pada Lanjut Usia Sebelum Pemberian Hidroterapi Kaki}

Hasil skoring insomnia sebelum dilakukan pemberian hidroterapi kaki didapatkan seperti yang ditampilkan pada tabel 5.1. Distribusi skor insomnia yang didapat dari hasil kuesioner pengukuran insomnia yang menggunakan kuesioner Insomnia Rating Scale yang telah dimodifikasi sesuai dengan kondisi lanjut usia di Indonesia oleh Kelompok Study Psikiatri Biologi Jakarta (KSPBJ) yaitu skor berkisar mulai yang terendah 22 hingga skor tertinggi 34. Menurut penggolongan Insomnia Rating Scale skor 20-27 termasuk dalam insomnia ringan, dan skor 28-36 termasuk dalam insomnia (Kelompok Studi Psikiatri Biologi, 1985).

Hampir semua orang pernah mengalami kesulitan tidur atau yang sering disebut insomnia, namun lanjut usia lebih sering mengalami kesulitan tidur jika dibandingkan dengan usia-usia yang lebih muda. Insomnia lebih banyak terjadi pada lanjut usia dikarenakan faktor usia yang semakin menua. Lanjut usia menurut WHO diklasifikasikan mulai dari usia 6074 tahun, dan Lanjut Usia Tua mulai dari usia 75-90 tahun. Usia yang semakin menua ini menyebabkan kondisi fisiologis tubuh juga ikut berubah. Insomnia pada lanjut usia ini disebabkan karena menurunnya produksi hormon melatonin, dimana hormon melatonin ini berfungsi sebagai hormon yang mengontrol sikardian tidur, atau disebut hormon tidur. Sekresi hormon melatonin terutama terjadi pada malam hari. Apabila terpajan dengan cahaya terang, sekresi melatonin akan berkurang (Kemenkes RI, 2013).

Hasil dari penelitian yang dilakukan, responden penelitian rata-rata berusia 75 tahun. Pada usia 75 tahun ini tubuh sudah mengalami perubahan fisiologis dimana dari segi sekresi hormon, hormon melatonin atau yang mengontrol siklus sikardian tidur ini mulai berkurang produksinya didalam tubuh. Pengurangan sekresi hormon melatonin ini pada responden ditunjukkan dengan adanya perubahan pada siklus tidurnya. Responden lansia ini mengalami gangguan tidur dibuktikan dengan hasil pengukuran insomnia dengan menggunakan Insomnia Rating Scale (Kelompok Studi Psikiatri Biologi, 1985).

Tinggi rendahnya tingkat insomnia pada lanjut usia terjadi karena adanya perbedaan faktor penyebab insomnia. Faktor yang dapat menyebabkan insomnia pada lanjut usia antara lain rasa nyeri, kecemasan, ketakutan, tekanan jiwa atau faktor psikologis, faktor lingkungan yang tidak bisa mendukung untuk tidur, dan perubahan pola tidur yang tidak teratur (Guyton \& Hall, 2006). 
Lanjut usia yang kurang tidur dapat menyebabkan penurunan daya tahan tubuh, tubuh terasa lemah dan cepat lelah, dan tanda-tanda vital tidak stabil. Tubuh manusia normal membutuhkan waktu istirahat minimal 8 jam perhari untuk mengembalikan kebugaran tubuh. Tidur sangatlah penting untuk manusia sehingga keluhan insomnia pada lanjut usia perlu segera diatasi (Kane \& Ouslander, 2009).

\section{Skor Insomnia Pada Lanjut Usia Sesudah Pemberian Hidroterapi Kaki}

Pengukuran skor insomnia kembali diukur menggunakan kuesioner Insomnia Rating Scale. Cara untuk mengatasi insomnia terdapat dua cara, antara lain dengan cara farmakologis dan cara nonfarmakologis. Salah satu langkah nonfarmakologis yang dapat menurunkan insomnia adalah dengan hidroterapi kaki. Hidroterapi kaki adalah bentuk dari terapi latihan yang menggunakan modalitas air hangat di dalam kolam. Dasar utama menggunakan air hangat untuk pengobatan dalam hidroterapi kaki ini adalah efek hidrostatik dan hidrodinamik. Efek hidrostatik adalah efek yang dihasilkan oleh daya dorong air ke atas sehingga dapat berguna untuk melatih tulang belakang dan sendi-sendi tulang. Efek hidrodinamik adalah variasi pergerakan dalam air yang berguna untuk menguatkan otot dan ligamen serta melancarkan peredaran darah dan sistem pernafasan (Guyton \& Hall, 2006).

Penelitian hidroterapi kaki ini diberikan selama 10 menit selama 4 hari dan dilakukan 1 jam sebelum tidur. Sesuai dengan sebuah teori yaitu untuk mendapatkan hasil yang efektif dari terapi rendam air hangat pada kaki sebaiknya dilakukan sebelum tidur malam. Lakukan secara rutin selama 3 - 6 hari, maka akan memberikan relaksasi pada tubuh sehingga dapat mengatasi gangguan tidur (Christina, 2012).

\section{Perbedaan Skor Insomnia Pada Lanjut Usia Sebelum Dan Sesudah Diberikan Hidroterapi Kaki}

Hasil analisa data dengan uji statistik Paired T-Test menggunakan bantuan aplikasi SPSS didapatkan bahwa ada pengaruh hidroterapi kaki terhadap penurunan insomnia pada lansia. Hasil analisa data didapatkan hasil bahwa semua responden mengalamani penurunan skor insomnia setelah diberikan hidroterapi kaki. Hasil analisa data tersebut juga sudah dapat dilihat bahwa ada penurunan skor insomnia antara sebelum dan sesudah diberikan hidroterapi kaki.

Hasil uji Paired T-Test juga didapatkan bahwa dengan tingkat kemaknaan 0,05 hasil signifikasi yang diperoleh sebesar 0,000. Hasil signifikansi $<0,05$ maka hal ini menandakan bahwa hidroterapi kaki yang diberikan pada lanjut usia ini memiliki pengaruh terhadap penurunan insomnia. Karena signifikasi < 0,05 maka hipotesis diterima. Hasil penelitian ini disimpulkan bahwa ada pengaruh hidroterapi kaki terhadap penurunan insomnia pada lanjut usia.

Penurunan insomnia ini disebabkan karena hidroterapi kaki ini merupakan salah satu cara untuk mengatasi insomnia. Selain itu hidroterapi kaki yang dilakukan selama 10 menit dan dilakukan sebelum tidur ini cukup efektif untuk mengurangi gangguan tidur terutama gejala insomnia. Hidroterapi kaki ini berpengaruh terhadap peningkatan pemenuhan tidur secara kualitas maupun kuantitas karena hidroterapi kaki memberikan rangsangan pada kaki yang dapat menstimulasi diproduksinya hormon melatonin yang dapat memperbaiki kuantitas dan kualitas tidur pada lanjut usia (Setyoadi \& Kushariyadi, 2011). Untuk mendapatkan hasil yang efektif, rendam air hangat pada kaki sebaiknya dilakukan sebelum tidur malam. Lakukan secara rutin selama 3 - 6 hari, maka akan memberikan relaksasi pada tubuh sehingga dapat mengatasi gangguan tidur (Khotimah, 2012). 
Merendam kaki dalam air hangat yang bertemperatur 30-39 derajat celcius akan menimbulkan efek sopartifik atau efek ingin tidur dan dapat mengatasi gangguan tidur. Didaerah kaki secara fisiologis terdapat banyak saraf terutama di kulit yaitu flexus venosus dari rangkaian saraf ini stimulasi diteruskan ke kornu posterior kemudian dilanjutkan ke medulla spinalis, dari sini diteruskan ke lamina I, II, III Radiks Dorsalis, selanjutnya ke ventro basal talamus dan masuk ke batang otak tepatnya di daerah rafe bagian bawah pons dan medulla, dari rangsangan inilah kelenjar pineal mensekresikan hormon melatonin yang dapat memperbaiki tidur (Guyton \& Hall, 2006).

\section{KESIMPULAN}

Berdasarkan hasil penelitian dan pembahasan dapat disimpulkan bahwa hidroterapi sangat efektif dalam membantu lansia unruk mengatasi insomnia dan meningkatkan kualitas tidur pada usia lanjut.

\section{SARAN}

Berdasarkan hasil penelitian disarankan pada pansia yang tinggal di panti werdha perlu dilakukan pemberian hidroterapi secara rutin dalam rangka meningkatkan rasa nyaman dan mambantu meningkatkan kepulasan tidur.

\section{KEPUSTAKAAN}

Amir, N. 2007. Gangguan Tidur pada Lanjut Usia Diagnosis dan Penatalaksanaan. Jakarta : Bagian Psikiatri FKUI. Hal. 196.

Amirta, Y. 2007. Sehat Murah dengan Air. Purwokerto : Keluarga Dokter.

Akmal, I. 2006. Seri Menata Rumah Kamar Mandi. Jakarta : PT. Gramedia Pustaka Utama. Hal. 31.

Asmadi. 2008. Teknik Prosedural Konsep dan Aplikasi Kebutuhan Dasar
Klien. Jakarta : Salemba Medika. Hal. 134.

Christina, LP. 2012. Pengaruh Terapi Rendam Kaki Air Hangat Terhadap Perubahan Tekanan Darah pada Penderita Hipertensi. (Abstract).

Erliana, E, et al. 2008. Perbedaan Tingkat Insomnia Lansia Sebelum dan Sesudah Latihan Relaksasi Otot Progresif (Progresif Muscle Relaxation) di BPSTW Ciparay Bandung.

Guyton and Hall. 2006. Textbook of Medical Physiology Eleventh Edition. Philadelphia : Elsevier Saunders.

Kane, R. and Ouslander, J. et al. 2009. Essentials of Clinical Geriatrics, Sixth Edition. United States : The McGraw-Hill Companies, Inc. Hal. 19.

Kelompok Studi Psikiatri Biologi Jakarta. 1985. Insomnia Rating Scale.

Kemsos RI. 2007. Penduduk Lanjut Usia Di Indonesia Dan Masalah Kesejahteraannya.

https://www.kemsos.go.id/modules .php? name $=$ News $\&$ file $=$ print $\&$ sid $=$ 522. Diakses tanggal 5 Juli 2016.

Kemenkes RI. 2013. Gambaran Kesehatan Lanjut Usia di Indonesia. Buletin Jendela Data dan Informasi Kesehatan Semester 1. Jakarta.

Khotimah, 2012. Pengaruh Rendam Air Hangat pada Kaki dalam Meningkatkan Kualitas Tidur Lansia.

Kristyarini D, Kristanti EE. 2012. Pengaruh Rendam Air Hangat pada Kaki Terhadap Kuantitas Tidur pada Lansia yang Mengalami Gangguan Tidur di Panti Wredha Santo Yoseph Kediri.

Setyoadi \& Kushariyadi, 2011. Terapi Modalitas Keperawatan pada Klien Psikogeriatrik. Jakarta : Medika Salemba. Hal. 143 